\title{
The Freshwater Animal Diversity Assessment: an overview of the results
}

\author{
E. V. Balian · H. Segers $\cdot$ C. Lévêque · \\ K. Martens
}

Published online: 12 February 2008

(C) Springer Science+Business Media B.V. 2008

\section{Erratum to: Hydrobiologia \\ DOI 10.1007/s10750-007-9246-3}

In the last paragraph of the Conclusion (page 636), lines $5 / 6$, the website for the FADA database should be given as $<\mathrm{http} / / /$ fada.biodiversity.be $>$.

The online version of the original article can be found under doi: 10.1007/s10750-007-9246-3.

Guest editors: E. V. Balian, C. Lévêque, H. Segers \& K. Martens

Freshwater Animal Diversity Assessment

E. V. Balian · H. Segers

Belgian Biodiversity Platform, Brussels, Belgium

E. V. Balian $(\square) \cdot$ H. Segers · K. Martens

Freshwater Biology, Royal Belgian Institute of Natural

Sciences, Vautierstraat 29, Brussels 1000, Belgium

e-mail: estelle.balian@naturalsciences.be

C. Lévêque

Antenne IRD, MNHN-DMPA, Case Postale 26,

43 rue Cuvier, Paris Cedex 05 75231, France

K. Martens

Department of Biology, University of Ghent,

K.L. Ledeganckstraat 35, Gent 9000, Belgium 